\title{
Przejawy narcystycznej konsumpcji w wybranych środowiskach graczy
}

\author{
Magdalena KozyrA
}

\begin{abstract}
Streszczenie
Celem niniejszego artykułu jest ukazanie sposobu, w jaki narcystyczna tożsamość graczy i związana z nią konsumpcja wpływają na formy uczestnictwa w kulturze gier wideo. Analizie poddany został sposób, w jaki odbiorcy biorą udział we współczesnej kulturze popularnej, oraz obraz modelowego gracza, który powstał pod koniec ubiegłego wieku. Przywołując kluczowe wydarzenia, mające miejsce w środowisku graczy w ciągu ostatnich lat, takie jak powstanie ruchu Gamergate, ukazano istniejący w jego obrębie mechanizm wykluczania, który do dzisiaj zauważalny jest w konserwatywnych grupach graczy gier cyfrowych.
\end{abstract}

Słowa kluczowe: kultura gier wideo, gry cyfrowe, kultura uczestnictwa, gracz, narcyzm, tożsamość

Magdalena Kozyra doktorantka kulturoznawstwa na Wydziale Polonistyki Uniwersytetu Jagiellońskiego. Jej zainteresowania badawcze związane są ze współczesną kulturą popularną, swoją rozprawę doktorską przygotowuje na temat doświadczenia porażki w grach wideo. E-MAIL:m.e.kozyra@gmail.com 
Czy można powiedzieć, że współczesna kultura uczestnictwa jest przejawem narcystycznego pragnienia naznaczenia tekstu tożsamością konsumenta? Opinie badaczy wydają się taką możliwość potwierdzać. Grzegorz Ptaszek, we wstępie do książki Kultura narcyzmu Christophera Lascha, traktującej o przejawach narcyzmu w społeczeństwie amerykańskim, pisze: „W kulturze narcyzmu liberalizm istnieje tylko w takim zakresie, w jakim służy społeczeństwu konsumpcyjnemu. Jednostka dba tak naprawdę tylko i wyłącznie o dobro własnego »ja« (self), skupia się na zaspokajaniu własnych pragnień, które wciąż jednak pozostają niezaspokojone" (Ptaszek 2019, 32). Nie należy jednak traktować tego zdania nadmiernie wartościująco. Potrzeba odnalezienia własnego „ja” w tekstach kultury popularnej zdaje się być odruchem nie tylko naturalnym dla większości odbiorców, ale również niezwykle pożądanym we współczesnym świecie - stanowi jedną z możliwości zwiększenia różnorodności w tekstach kultury. Ta pozytywna forma narcystycznego konsumpcjonizmu, a więc próby odnajdywania tekstów tożsamych z poglądami odbiorcy oraz dostosowania tekstów do własnych potrzeb, jest w stanie pomóc zdiagnozować stan współczesnej kultury popularnej i ukazać jej braki, a nawet ukryte mechanizmy dyskryminacji. Należy się jednak spodziewać, że nie wszystkie formy narcystycznego konsumpcjonizmu mają i będą mieć pozytywny charakter.

W niniejszym artykule chciałam przyjrzeć się wybranym grupom odbiorców gier wideo, nie tylko samoidentyfikujących się jako gracze, ale również wyrażających konserwatywne poglądy odnoszące się do prezentowanych $\mathrm{w}$ grach treści oraz niechęć do zachodzących na tym polu zmian w przemyśle gier wideo, aby wskazać, w jaki sposób negatywna forma narcystycznego konsumpcjonizmu jest w stanie wpłynąć na konkretne społeczności, a nawet współczesną kulturę popularną w ogóle. Sposób, w jaki ukształtowała się kultura graczy ${ }^{1}$, w dużej mierze ukazuje cechy charakterystyczne dla zbiorowej tożsamości narcystycznej, będącej, jak pisze Miłosz Wojtyna, sposobem na „skonsolidowanie (»usztywnienie«) pewnej fikcjonalnej wersji tożsamości, wokół której da się zogniskować całe społeczne funkcjonowanie jednostki lub grupy pomimo ewidentnego braku mitu założycielskiego (albo innych autentycznych podstaw do samozadowolenia)" (Wojtyna 2018, 25). Warto również wspomnieć, że ważnym momentem dla kultury graczy była

1 Obecnie należałoby mówić raczej o kulturach graczy, ponieważ opisanie tak licznej i niejednorodnej grupy, jaką stanowią dzisiaj użytkownicy gier wideo, w homogeniczny i spójny sposób wydaje się wręcz niemożliwe. 
próba zredefiniowania pojęcia „gracz”, zapowiadająca zarazem kryzys ${ }^{2}$ ich tożsamości (Mortensen 2016, 4; Bednorz 2015; Condis 2015) - wydarzenia te zbiegły się w czasie z ruchem Gamergate, o którym pisać będę w dalszej części artykułu, wskazując na niestabilność kultury gier i zachodzące w niej zmiany (niekoniecznie pożądane przez wszystkie grupy graczy). Paweł Tomczok za Erichem Frommem wspomina, iż zbiorowa tożsamość narcystyczna „pojawia się nie w każdej sytuacji, gdy grupa określa siebie jako pewną wielką całość, ale wtedy, gdy wcześniejsze określenia zostały zniszczone, zaatakowane, gdy ustalone znaczenia tożsamości zbiorowej uległy degradacji” (Tomczok 2018, 93). Wydaje mi się, że pojęcia narcystycznej konsumpcji oraz narcystycznej tożsamości zbiorowej są w stanie wytłumaczyć działania podejmowana przez niektóre grupy graczy, którzy w taki a nie inny sposób, reagowali na zmiany zachodzące w kulturze gier.

\section{Od konsumowania do współtworzenia kultury popularnej}

Wraz z pojawieniem się i rozwojem mediów 2.0 wyłonił się nowy sposób konsumowania treści i uczestnictwa w kulturze: uzyskano dostęp do szybkiego przepływu informacji i możliwość nawiązywania bezpośrednich kontaktów z innymi użytkownikami, powszechne stały się narzędzia umożliwiające łatwe przetwarzanie dostępnych tekstów kultury. Na początku obecnego wieku badacze, diagnozujący dopiero formującą się kulturę uczestnictwa, wychwalali demokratyczny dostęp do kultury, a także charakterystyczny, w szczególności dla grup fanowskich, sposób aktywnego konsumowania treści (Jenkins 2006). Użytkownik nowych mediów przestał być postrzegany jako bierny konsument, którego krytyczny odbiór polegał w głównej mierze na interpretowaniu tekstów kultury - stał się aktywnym współtwórcą, biorącym udział w przetwarzaniu produkowanych treści (Dovey, Kennedy 2011). Tak zwany prosument (produkujący konsument), opisany na polskim gruncie przez Piotra Siudę (Siuda 2012), stał się modelową figurą reprezentującą aktywnego użytkownika charakteryzującego się krytyczną postawą odbior-

${ }^{2}$ Kryzys tożsamości gracza wiąże się głównie z popularyzacją gier cyfrowych, a co za tym idzie, z pojawieniem się casualowych (niezaangażowanych) graczy, którym zostaje przeciwstawiony model hardcorowego (zaangażowanego) gracza (Garda 2016, 110-131; Grabarczyk 2019, 127-148). 
czą, a także potrzebą przerabiania tekstów według swoich własnych upodobań i konsumenckich potrzeb. Za przykład idealnej postawy prosumenckiej może posłużyć fan, który za pomocą rozlicznych aktywności fanowskich, takich jak tworzenie fanartów czy fanfików na podstawie tekstu źródłowego, ukazuje świat przedstawiony i relacje między bohaterami ze swojej własnej perspektywy. Produkcja fanowskich artefaktów wskazuje między innymi na odbiorcze zaangażowanie, a także szeroką wiedzę o tekście kanonicznym, który następnie zostaje poddany przeróbce według potrzeb danego fana.

Teksty kultury popularnej, wytwarzane w dobie opisanej przez Henry'ego Jenkinsa kultury uczestnictwa, miały zachęcać odbiorców do takiej właśnie aktywnej partycypacji - tworzenia własnych paratekstów, opartych na konsumowanych produktach, czy snucia domysłów nad przyszłymi losami bohaterów, tym samym podkreślając krytyczny i zaangażowany odbiór współczesnego użytkownika mediów (Jenkins 2006). Utopijna wizja demokratycznej partycypacji, zrównująca rolę producenta i konsumenta, oraz krytyczna postawa odbiorcy kultury popularnej, akcentowane między innymi przez Jenkinsa czy Johna Fiske’a (Fiske 2010), wpłynęły znacząco na sposób, w jaki dzisiaj mówi się w szczególności o społecznościach fanowskich. Te ostatnie stały się w optyce wymienionych badaczy przestrzenią partyzantki semiotycznej (Eco 1996), której celem jest wyrażenie sprzeciwu wobec kultury głównego nurtu. W takiej idealistycznej wizji kultura uczestnictwa motywuje fanów do przyjęcia postawy krytycznej, obnażającej dyskryminujące mechanizmy kultury popularnej i - poprzez swój sprzeciw wobec sposobu przedstawiania bohaterów i ich tożsamości - mającej sprawić, że w przyszłości stanie się ona bardziej inkluzywna i wrażliwa na inność.

Należy jednak pamiętać, że jest to niewątpliwie wizja utopijna: Jenkins przeceniał rolę fanów w tworzeniu i wpływaniu na teksty kultury popularnej, między innymi nie dostrzegając roli producentów, którzy znakomicie rozpoznają aktywność społeczności fanowskich oraz sposób ich zaangażowania w kulturę popularną. W odpowiedzi na działalność fanowską twórcy wypracowali nowe strategie zaangażowania, wprowadzając wątki rozpoznawalne jedynie przez wtajemniczonych odbiorców, jednocześnie nie ryzykując utraty masowego zainteresowania poprzez ukazywanie potencjalnie kontrowersyjnych treści, które mogłyby zniechęcić przeciętnego konsumenta. Przykładem takich praktyk może być chociażby strategia queerbaitingu (budowania seksualnego napięcia między bohaterami tej samej płci, bez jednoznacznego potwierdzenia istnienia między nimi relacji erotycznej 
bądź romantycznej), mająca przyciągnąć nieheteronormatywną widownię, bez jednoczesnego umieszczania $\mathrm{w}$ tekście otwarcie queerowej reprezentacji (Kobus 2017). O ile jednak trudno określić granice krytycznego odbioru i wpływu konsumentów na kulturę popularną, o tyle łatwo można zgodzić się z twierdzeniem, że charakter uczestnictwa w mediach 2.0 wytwarza poczucie demokratycznego dostępu do kultury, a także wrażenie możliwości bezpośredniego wpływu na ukazywane w niej treści. To poczucie konsumenckiej sprawczości przejawia się między innymi w ułatwionym, za sprawą mediów społecznościowych, dostępie do samych twórców popkultury: wysłanie prywatnej wiadomości czy opublikowanie komentarza na profilu reżysera, producenta czy aktora pozostawia nadzieję, że głos konsumenta zostanie wysłuchany. Niekiedy tak też się dzieje, czego przykładem może być opuszczenie konta na Twitterze przez Jossa Whedona z powodu agresywnej krytyki nadsyłanej przez fanów Marvela po premierze opartego na jego scenariuszu i reżyserowanego przez niego filmu Avengers: Czas Ultrona.

Konsument współczesnej popkultury staje się figurą ważną dla producentów z wielu powodów. Nie chodzi jedynie o dopasowanie się do masowych gustów i obecnych trendów, by sprzedać produkt zadowolonym konsumentom, ale również o sposób, w jaki użytkownicy są w stanie wpłynąć na promowanie produktu, a także na jego komercyjny sukces. Pojęcia takie jak prosument (Siuda 2012), praca afektywna (Terranova 2000) czy digital labor (Scholz 2013) odnoszą się do pracy wykonywanej przez użytkowników $\mathrm{w}$ czasie wolnym. Z perspektywy wymienionych teorii, czynności, takie jak komentowanie wpisów czy produkcja fanowskich gadżetów, postrzegane są w kategoriach pracy na rzecz cudzego zysku. Kultura uczestnictwa jest zatem także jednym ze zjawisk ukazujących odbiorców samoistnie napędzających przemysł rozrywkowy i tym samym uwalniających producentów od dodatkowej pracy, jaką jest utrzymywanie zainteresowania danym produktem wśród jego odbiorców. Za przykład mogą posłużyć gracze tworzący modyfikacje gier komputerowych (mody), które wprowadzają zmiany do oryginalnej gry, takie jak ulepszenia grafiki czy wyglądu postaci. Największym zainteresowaniem, wśród użytkowników służącej do ich rozpowszechniania platformy Nexus Mods, cieszą się mody do gry Skyrim, piątej części serii The Elders Scrolls, która swoją premierę miała w roku 2011. Z powodu decyzji studia o udostępnieniu oficjalnych narzędzi do jej edycji, gra do dzisiaj jest 
jednym z najczęściej modowanych tytułów ${ }^{3}$, co równocześnie napędza sprzedaż i zainteresowanie samym produktem.

Forma, z jaką współczesny odbiorca angażuje się w konsumowane treści, zbliżona jest do sposobu, w jaki Ptaszek opisuje zachowania narcystyczne w cytowanym już fragmencie. Chodzi mianowicie o konsumpcyjne „zaspokajani[e] własnych pragnień, które wciąż jednak pozostają niezaspokojone" (Ptaszek 2019). Sytuacja znacznie bardziej komplikuje się jednak w momencie, kiedy większa grupa odbiorców wyraża podobne potrzeby, takie jak dostosowanie tekstów do jej gustów, a także odmawianie konsumpcji innym grupom odbiorców. Zajmujący się pojęciem zbiorowego narcyzmu Erich Fromm zauważa, iż w przeciwieństwie do indywidualnego narcyzmu, narcyzm zbiorowy cieszy się poparciem wielu jednostek, dlatego też łatwiej może przezwyciężać przeszkody, które napotka na swojej drodze (Fromm 2016). Konsumpcja, będąca jednocześnie wyrazem postawy narcystycznej i uprzywilejowania niektórych grup społecznych widoczna jest do dzisiaj w kulturach graczy, w których obrębie potrafi niekiedy przyjąć agresywne wręcz formy.

\section{Jak marketing wytworzył tożsamość gracza}

Sposób postrzegania gier komputerowych i ich graczy do dzisiaj zdaje się wiązać raz z obalaniem, raz z utrwalaniem stereotypów z nimi związanych. Pomimo wielokrotnie pojawiających się badań statystycznych, które miały raz na zawsze podważyć dominujące przeświadczenie, że największy procent graczy stanowią mężczyźni, badacze zgodnie stwierdzają, iż „gry wciąż postrzega się jako domenę mężczyzn” (Tuła 2013, 281), „gry komputerowe nadal są kojarzone przede wszystkim z mężczyznami, a gracze przedstawiani zazwyczaj jako jednolita grupa” (Bednorz 2015, 16), czy „narracyjnie światy gier komputerowych są mocno zakodowane jako męskie - nie tylko pod względem zawartości, ale też tego, jak się je sprzedaje, umiejscawia, wymienia i ocenia" (Dovey i Kennedy 2011, 46). Dlatego akurat to medium, w przeciwieństwie do filmów czy seriali, wciąż przypisane pozostaje jednej płci? Co sprawiło, że gry wideo postrzegane są jako rozrywka typowo męska?

3 Dane z dnia 11 listopada 2019 roku wskazują, że na stronie internetowej Nexus Mods do gry Skyrim, oraz jej specjalnej edycji (Skyrim Special Edition) powstały łącznie 82 tysiące modów. Na drugim miejscu znajduje się gra Fallout 4 z liczbą 30 tysięcy modów. Dane ze strony internetowej: www.nexusmods.com. 
Pierwsza gra cyfrowa, która została udostępniona szerszej publiczności, powstała w 1972 roku i nazywa się Pong (Mäyrä 2008, 58). Zadaniem dwóch rywalizujących graczy było odbicie piłeczki w stronę przeciwnika. Można zatem uznać, że treść gry nie sugeruje skierowania jej do konkretnej płci. Pong, a także kolejne gry na konsole, miały być odbierane jako rodzinna rozrywka, którą można się cieszyć w gronie przyjaciół. Jak wskazuje Tracey Lien, pierwsze konsole do gier nie posiadały żadnej grupy targetowej: „nie było osób $\mathrm{z}$ doświadczeniem marketingowym w przemyśle gier, ponieważ przemysł gier wideo nigdy wcześniej nie istniał" (Lien 2013) ${ }^{4}$. Rynek jednak szybko nasycił się nowym produktem, a zainteresowanie nowym medium w roku 1983 spadło tak gwałtownie, że dzisiaj data ta znana jest jako moment pierwszej zapaści rynku gier wideo. Aby uratować dopiero powstający przemysł, sprzedawcy postanowili określić grupę odbiorców nowych produktów, do których skierowane będą treści marketingowe, tym samym stwarzając rynek zbytu dla okrytych złą sławą konsol do gier. Główną grupą targetową zostali - z niewielką przewagą procentową - chłopcy. Wybór takiej, a nie innej grupy wiązał się nie tylko ze statystykami, z których wynikało, że dominującą (w niewielkim stopniu) płcią wśród graczy są chłopcy, ale również z konotacjami związanymi z samą dziedziną technologii:

Gry komputerowe wyłoniły się w serii kontekstów uznawanych za męską domenę (fizyka, matematyka, technologia, wojskowość) i przez to odziedziczyły ten konkretny kod kulturowy. Dziś sytuacja pozostaje taka sama jak na początku lat osiemdziesiątych XX wieku, pomimo wielu inicjatyw motywowanych komercyjnie i politycznie, które chciały zmienić kulturową tożsamość gier komputerowych. (Dovey i Kennedy 2011, 45)

Chłopcy nie tylko stanowili procentowo większą grupę graczy, ale również kulturowo postrzegani byli jako bardziej odpowiedni konsumenci, którzy posiadali uprzywilejowany dostęp do dziedzin związanych z nowymi technologiami. O ile pierwsze reklamy konsol do gier skierowane były do wszystkich, o tyle na plakatach promujących Game Boye pojawiali się już tylko chłopcy (Lien 2013). Oczywiście, dziewczyny wciąż chętnie sięgały po gry wideo, jednak nie tylko nie były one większością wśród graczy, ale również przestały pojawiać się na materiałach promocyjnych - to nie do nich skierowany był produkt: „Pogoń za bezpiecznym i pewnym rynkiem

${ }^{4}$ Jeżeli nie zaznaczono inaczej, tłumaczenia pochodzą od Autorki artykułu - przyp. red. 
w branży gier sprawiła, że skupiła się ona na młodym mężczyźnie. I tak zaczęły się kampanie reklamowe. Gry wideo były reklamowane jako produkty dla mężczyzn, a przesłanie było jasne: dziewczyny nie mają wstępu” (Lien 2013). Był to zdecydowanie ważny moment w historii gier wideo, ponieważ właśnie wtedy gry pojawiające się na rynku zaczęły być tworzone głównie z myślą o męskim graczu.

Kiedy grupa targetowa została już określona, twórcy mainstreamowych gier „stwierdzili, że zasady większości gier będą wymagać od graczy agresywnych, »męskich « zachowań" (Condis 2015, 200). Ogromna część gier powstających w kolejnych latach, albo też sposób, w jaki dane gry reklamowano, narodziły się właśnie z tej wizji - męskich gier, tworzonych dla męskich graczy. Automatycznie zaczął wytwarzać się zamknięty obieg, wykluczający, nie tylko w kampaniach reklamowych, ale również w samej treści produktów, osoby niezainteresowane taką zawartością gier. W tych warunkach wykształcił się obraz modelowego męskiego gracza, uniemożliwiając pojawianie się alternatywnych narracji, przeznaczonych dla odbiorców o innych gustach. Jak słusznie zauważa Adrienne Shaw, „Brak obecności grup marginalizowanych $\mathrm{w}$ grach wideo często wiąże się z faktem, że przemysł nie myśli o członkach tych grup jak o graczach" (Shaw 2011, 28). Powielający się przez kolejne lata schemat - zarówno prezentowanego odbiorcy, jak i preferowanej przez niego tematyki gier - wpłynął na sposób w jaki gracze zaczęli myśleć o sobie samych. Taki sposób identyfikacji tożsamy jest z opisanym już modelem budowania zbiorowej tożsamości narcystycznej, opartej na „fikcjonalnej wersji tożsamości, wokół której da się zogniskować całe społeczne funkcjonowanie jednostki lub grupy pomimo ewidentnego braku mitu założycielskiego" (Wojtyna 2018, 25).

Młodzi chłopcy, wychowani na pierwszych konsolach do gry, zaczęli dorastać. Fakt ten nie pozostał niezauważony przez przemysł gier, który postanowił wypróbować nową formę reklamy, która z kolei przyciągnie uwagę nastolatków i młodych mężczyzn: „Firma Atari nakręciła serię dziwacznych reklam, które ukazywały, jak bardzo życie mężczyzny się polepszy, jeśli zakupi on najnowszą konsolę Jaguar. Z każdym »ulepszeniem « wzdychały do niego coraz piękniejsze kobiety" (Lien 2013).

Zainspirowani taką formą oficjalnego marketingu gracze wykorzystali ową estetykę we własnym obiegu, wytwarzając zjawisko nerdcore: zapożyczając formę amatorskich zdjęć pornograficznych, przedstawiali nagie kobiety w środowisku gracza - otoczone grami wideo oraz innymi przedmiotami 
przeznaczonymi dla graczy (warto zaznaczyć, że kobiety te przyjmują rolę pasywną i nie grają w gry, a jedynie pozują w ich otoczeniu). Tym samym utrwalił się obraz atrakcyjnej kobiety w otoczeniu rekwizytów gracza, nigdy jednak nie używającej ich zgodnie z przeznaczeniem - czyli do uczestnictwa w rozgrywce. Tom Apperley pisze: „Kalendarz »To jest Nerdcore« przedstawiał granie jako męską, heteroseksualną aktywność, gdzie kobiety stanowiły obiekty przyjemności wizualnej. Wykorzystano istniejący już trop, kultywowany przez przemysł gier od lat” (Apperley 2019).

W ten sposób ostatecznie i definitywnie kobiety zostały wykluczone z kultury grania, w której pojawić się mogły już tylko jako roznegliżowane i przyjemne dla męskiego spojrzenia dodatki. Atrakcyjna kobieta miała zachęcić do kupna gry, jednak w oczach graczy nie posiadała żadnych kompetencji, by sama mogła sięgnąć po dany tytuł. Myślę, że taki sposób marketingu utrwalił również obraz, który dzisiaj upowszechnił się pod nazwą Fake Gamer Girl. Chodzi mianowicie o sposób, w jaki często oceniane są kobiety, które przyznają się do grania w gry komputerowe: automatycznie posądzane są one jedynie o próbę wzbudzenia zainteresowania mężczyzny, ponieważ im samym przypisuje się brak odpowiednich kompetencji, a ich zacięcie do gier odbierane jest jako z natury fałszywe ${ }^{5}$.

Kobiety oraz gry skierowane specjalne do nich ${ }^{6} \mathrm{w}$ niektórych środowiskach graczy traktowane są w najlepszym wypadku z lekceważeniem i wyższością. Przykładem może być społeczna recepcja serii gier The Sims, która momentalnie została okrzyknięta grą dla dziewczyn i dzieci. Symulacje pozbawione wartkiej akcji czy niewymagające określonych zdolności, takich jak zręczność i umiejętność posługiwania się klawiaturą lub kontrolerem, często uznawane są przez doświadczonych graczy za gorsze. Czasami nawet odmawia im się statusu gry (preferowanym określeniem staje się wtedy „symulacja komputerowa”), jak stało się w przypadku Gone Home, tytułu opowiadającego o odkrywaniu nienormatywnej tożsamości seksualnej przez nastolatkę (Pavlounis 2016, 2). Jak zauważa Magdalena Tuła:

Mimo że kobiety stanowią niemal połowę graczy, ich granie zachodzi niejako poza kulturą gier komputerowych [...]. Gatunki, w które grają przeważ-

${ }^{5}$ W podobny sposób powstał stereotypowy obraz Fake Geek Girl, która rzekomo interesuje się kulturą popularną tylko po to, aby zaimponować mężczyznom i wzbudzić ich zainteresowanie, faktycznie nie posiadając przy tym żadnej wiedzy związanej z tematem.

${ }^{6}$ Przykładem mogą być tak zwane Pink Games, skierowane głównie do młodych dziewczynek, które mają podejmować interesujące je, zdaniem twórców, tematy, takie jak gotowanie czy przebieranie księżniczek. 
nie mężczyźni, cieszą się większym prestiżem, w kulturze graczy są traktowane jako „prawdziwe gry”. Natomiast gatunki gier popularne wśród kobiet traktowane są jako łatwe, mało wymagające, mniej prestiżowe, odmawia się im także prawa do miana gry komputerowej. (Tuła 2013, 282)

Warto również wspomnieć, że wprowadzony przez marketing podział na gry wideo (z założenia skierowane dla mężczyzn) oraz gry dla dziewczyn umacnia jedynie istniejące już w kulturze gier podziały. Wydaje się więc, że uprzywilejowaną grupę odbiorców stanowią mężczyźni, pomimo faktu, iż współczesne reklamy, a także zawartość gier znacznie różnią się od tych powstających pod koniec ubiegłego wieku. Wykluczenia innych grup odbiorców przeniosły się jednak z pola marketingu do samych środowisk graczy, wskazujących, kto ma prawo uczestniczyć w kulturze gier i na jakich zasadach. Jaskrawy przykład, ukazujący ciągłe replikowanie wykluczających zachowań, stanowi chociażby seria OMG A GIRL, publikowana na platformie YouTube od 2018 roku (Spawntaneous 2019). Streamerka Spawntaneous udostępnia zapisy ze swojej rozgrywki online w strzelankę Tom Clancy's Rainbow Six Siege, ukazując reakcje innych graczy na obecność kobiet w przestrzeni (w powszechnej świadomości) wciąż zdominowanej przez mężczyzn - odmawia się jej prawa do uczestnictwa w rozgrywce, wyśmiewa, lekceważy, a momentami wręcz napastliwie zaczepia ${ }^{7}$.

\section{Gracze, których pozbawiono tożsamości}

W ciągu ostatnich lat zauważyć można rosnące zainteresowanie grami wideo (w Polsce sytuacja ta niewątpliwie związana jest z światowym sukcesem trzeciej części gry o Wiedźminie, wydanej przez studio CD Project RED w 2012 roku). W związku z przejściem kultury gier do głównego nurtu kultury popularnej, świadomość problemów istniejących w sposobach prezentowania treści obecnych w grach wideo zdaje się wśród twórców wzrastać: coraz częściej owe problemy są przez nich adresowane. Ten pozytywny trend dotyczący zmian zachodzących w kulturze gier wideo widoczny jest głównie za sprawą ukazujących się tytułów. Czołowym przykładem jest reboot serii gier o Larze Croft z lat 2013-2018, w którym wygląd i charakter bohaterki został dostosowany do wrażliwości współczesnego odbiorcy, dystansując

7 Podobne wnioski na temat marginalizowania i lekceważenia obecności kobiet oraz ich przedmiotowego traktowania we współczesnej kulturze gier wysnuwają autorzy artykułu Gamer girls: Navigating a subculture of gender inequality (Harrison, Drenten, Pendarvis 2016). 
się od jej pierwszych projektów, krytykowanych za nadmierną erotyzację postaci kobiecej (Kennedy 2002). Pojawiają się również alternatywne narracje, takie jak gry bezpośrednio nawiązujące do tożsamości queerowych (na przykład Life is Strange czy wspomniane już Gone Home).

Wydawać by się więc mogło, że kampanie reklamowe z lat osiemdziesiątych i dzisiejsza sytuacja w środowisku graczy nie mają już ze sobą nic wspólnego - minęly w końcu prawie cztery dekady, a rynek gier rozwinął skrzydła i zyskał wielu nowych odbiorców ${ }^{8}$. Jak jednak pisze Apperley, w niektórych środowiskach graczy wiąż zaobserwować można poczucie „nostalgii za przeszłością gier, kiedy kobiety były obecne, ale przedstawiane w erotyczny sposób, pragnienia stworzenia grania bardziej męskiego i seksualnego - podobnego do »kultury samochodów «” (Apperley 2019). Wytworzony pod koniec ubiegłego wieku wizerunek gracza utrwalił się w kulturze popularnej, wpływając nie tylko na sposób, w jaki wciąż postrzega się samą aktywność grania, ale również na metody samoidentyfikacji osób grających. To właśnie w zamkniętym środowisku graczy, które niechętnie dopuszczało do siebie głosy z zewnątrz i z podejrzliwością traktowało wszelkie próby wprowadzania zmian do medium gier, pojawił się ruch Gamergate, który eskalował w 2014 roku, ale, jak wskazują badacze, początku konfliktu można doszukiwać się już w roku 2007 (Mortensen 2016, 5). Wspominam o tym wydarzeniu, ponieważ jest ono niezwykle ważne dla kultury gier. Ukazuje mechanizmy wykluczające, $\mathrm{z}$ jakimi spotykają się w jej obrębie kobiety oraz osoby nieheteronormatywne, a także ze względu na wagę tego faktu dla kultury popularnej w ogóle9.

Oficjalnie \#gamergate ${ }^{10}$ rozpoczął się wraz z kampanią mającą na celu oczernienie projektantki gier Zoe Quinn, która została posądzona przez swojego byłego partnera o utrzymywanie stosunków seksualnych z jurorami, aby uzyskać pozytywne recenzje swojej gry Depression Quest. Konflikt

${ }^{8}$ Na co wskazuje przywoływany już podział na graczy hardcorowych i casualowych, związany z popularyzacją gier cyfrowych oraz opisaną przez Jespera Juula „casualową rewolucją”, która otworzyła rynek na nowe grupy odbiorców, głównie za sprawą pojawienia się nowych konsol i gier casualowych (Juul 2010).

9 W ostatnich miesiącach, na przykład, „zainspirowani” ruchem fani amerykańskiego komiksu zainicjowali Comicsgate, którego celem jest oskarżanie przemysłu superbohaterskiego o niepotrzebne wprowadzanie poprawności politycznej do treści komiksów.

${ }^{10}$ Ruch rozpoczął się wykorzystaniem na portalach społecznościowych hashtagu „gamergate”, który towarzyszył ostrej krytyce skierowanej w przemysł gier wideo, posądzany o umieszczanie w grach wymuszonej poprawności politycznej. 
szybko eskalował: kobiety zaangażowane w tworzenie i krytykę gier wideo również znalazły się pod ostrzałem członków Gamergate. Oskarżano je głównie o wprowadzanie poprawności politycznej do gier (takiej jak ukazywanie silnych kobiecych postaci czy queerowych treści), tłumacząc, iż stanowią one zagrożenie dla zamkniętej kultury męskich graczy. Poczucie strachu związane z utratą własnej tożsamości i kultury (Mortensen 2016, 11) poprzez wprowadzanie różnorodnych treści do nowych gier, a więc otwarcia środowiska na inne grupy społeczne, a także próba redefinicji pojęcia „gracz” przez środowisko akademickie, doprowadziły do otwartych przejawów agresji, poczynając od publikowania prywatnych informacji na temat atakowanych osób w mediach społecznościowych, a kończąc na grożeniu, między innymi Quinn i krytyczce gier wideo Anicie Sarkeesian, gwałtem i śmiercią, co doprowadziło do sytuacji, w której projektantka musiała zmienić miejsce zamieszkania, czy pojawiać się na wydarzeniach prasowych w otoczeniu służb mundurowych (Mortensen 2016, 6-7).

Innym przykładem była zmiana polityki studia BioWare, odpowiedzialnego za stworzenie serii popularnych gier, takich jak Mass Effect czy Dragon Age, do których zaczęto wprowadzać możliwość zawiązywania nieheteroseksualnych romansów. Studio, które, wraz z podjętą decyzją, straciło wielu fanów (zyskując jednak nowych odbiorców zainteresowanych obecnością queerowych bohaterów w grach), zmuszone zostało do zamknięcia oficjalnego forum z powodu agresywnych i negatywnych komentarzy umieszczanych przez konserwatywnych graczy. Krytykowali oni BioWare za pojawianie się w grach postaci homo- i biseksualnych, ale też za dodawanie różnych poziomów trudności gier, które miały sprawić, że osoby zainteresowane rozgrywką opartą bardziej na poznawaniu fabuły czy interakcjach z postaciami wewnątrz gry, niż na zręczności manualnej, również będą mogły czerpać z nich przyjemność. Warto tutaj zaznaczyć, że wprowadzane przez studio sposoby rozgrywki były opcjonalne, lecz sam fakt ich obecności wzbudzał niechęć i niezgodę ze strony niektórych graczy. Podobny przykład stanowią wzburzone komentarze graczy domagających się zwrotu pieniędzy za zakup gry Overwatch, w momencie, kiedy jej twórcy ogłosili, że jedna z bohaterek jest w związku z kobietą (warto zaznaczyć, że informacja ta została podana nie w samej grze, ale w komiksie, który opowiadał o jej bohaterach).

Postawa, jaką reprezentują opisane powyżej grupy konserwatywnych graczy, wiąże się z brakiem empatii, a także całkowitą niezgodą na inność. To jedne z negatywnych cech, jakie mogą przejawiać jednostki narcystyczne: 
„Każda forma narcyzmu społecznego otępia emocjonalnie całe zbiorowości, pozbawia je zdolności do empatii i czyni okrutnymi w stosunku do tych, którzy są poza naszą grupą. Wtedy to można niszczyć i podporządkowywać sobie bez poczucia winy to, co jest uważane za niższe, gorsze" (Olchanowski i Sieradzan 2011, 25). Niesamowita skala, jaką przybrało Gamergate, a także próby wprowadzania alternatywnych narracji do mainstreamowych gier komputerowych, ukazały, że negatywny stereotyp gracza w niektórych przypadkach rzeczywiście się sprawdza: „Istnieje dominujące przekonanie, że kultura grania jest w najlepszym wypadku heteronormatywna, a w najgorszym rażąco homofobiczna" (Shaw 2011, 28). Potwierdzają to również głosy samych graczy, którzy poczuli potrzebę reidentyfikacji tożsamości gracza i ponownego odnalezienia swojego miejsca w kulturze graczy: „Nie wydaje mi się, że wiele osób kłóciłoby się z faktem, że zdecydowana większość graczy gier RPG jest rzeczywiście heteroseksualnymi mężczyznami [...] To śmieszne, że muszę używać takiego określenia jak heteroseksualny męski gracz, kiedy w przeszłości mogłem po prostu powiedzieć »fani «" (Condis 2015).

Jak ukazuje powyższy cytat, niektórzy gracze, identyfikujący fana gier wideo z heteroseksualnym mężczyzną, poczuli zagrożenie dla własnej tożsamości i zamkniętej kultury, która nieubłagalnie zaczęła podlegać znaczącym zmianom związanym z regułami uczestnictwa w tej kulturze. Myśl, że gracz może nie być mężczyzną (nie wspominając już o jego potencjalnej nieheteronormatywności), nie znajdywała swojego miejsca w wypracowanym przez lata obrazie kultury grania. Jak pisze Laine Nooney:

Innymi słowy, nasze poczucie, że historia gier wideo „kręci się wokół chłopców" jest konsekwencją pewnego sposobu historycznego pisania, utrwalania, zapamiętywania i charakterystycznych dla danego momentu przywiązań afektywnych, które produkują sposób, w jaki opowiadamy historię gier wideo. (Nooney 2013)

Sposób, w jaki postrzegamy gry cyfrowe, a także ich kulturę i samych graczy, związany jest z wypracowanym przez branżę marketingiem, który najpierw stworzył odbiorców, a następnie wpływał na sposób kreowania tożsamości męskiego gracza, utrwalając ją przez kolejne lata. Powszechne założenie, że graczami zostają biali, heteroseksualni mężczyźni sprawiło, że to właśnie do nich kierowało się produkt i to właśnie ta grupa najczęściej po niego sięgała. Co więcej, grupa ta poczuła się na tyle uprzywilejowana i pewna 
swojego prawa do pierwszeństwa konsumpcji towarów, że zaczęła odmawiać dostępu do kultury gier innym grupom, a także z agresją reagowała na treści, które nie odpowiadały jej poglądom. Kultura graczy w przejaskrawiony sposób ukazuje sytuację, w której wybrana grupa odbiorców zyskała prawo do decydowania o formie i treści skierowanych do niej produktów, i - w rezultacie - stopniowo oduczyła się wrażliwości i akceptacji dla inności. Tę niezwykle niebezpieczną cechę społecznego narcyzmu Charles Taylor opisuje następująco: „kultura samorealizacji doprowadziła do tego, iż wielu ludzi straciło z oczu problemy, które przekraczają ich jednostkowy punkt widzenia" (Taylor 2002, 19). Co ciekawe, podobny wątek podjęła ostatnio Agata Sikora w swojej książce Wolność, równość, przemoc. Czego nie chcemy sobie powiedzieć. Badaczka zwraca uwagę na fakt, iż w niektórych przypadkach pozytywna potrzeba zwiększenia inkluzywności w kulturze popularnej może również doprowadzić do pomijania innych wykluczanych grup - skupiając się jedynie na sobie, pomijamy to, co jest obok nas. Autorka namawia więc czytelników do wyjścia poza jednostkowe problemy, a także zachęca do wrażliwości i nauki obcowania z tym, co inne (Sikora 2019). Wydarzenia, które miały miejsce w niektórych środowiskach graczy w ciągu ostatnich lat, pokazują, że być może jest to najtrudniejsze wyzwanie, jakie musimy podjąć w dobie wciąż rozwijającej się kultury uczestnictwa.

\section{Bibliography}

Apperley, Tom. 2019. „Gaming's secret public: Nerdcore porn, \#gamergate and the in/visible body of the female gamer”. Dostęp: 17.12.2019. https://www.academia.edu/13907585/Gamings_secret_public_Nerd core_porn_gamergate_and_the_in_visible_body_of_the_female_ gamer.

Bednorz, Magdalena. 2015. „Kryzys tożsamości gracza - znaczenie terminu »gamer « wobec popularyzacji gier komputerowych". Homo Ludens 2(8): $10-21$.

Condis, Megan. 2015. „No homosexuals in Star Wars? BioWare, 'gamer' identity, and the politics of privilege in a convergence culture". Convergence: The International fournal of Research into New Media Technologies 21(2).

Dovey, John, Helen W. Kennedy. 2011. Kultura gier komputerowych. Tłum. Tomasz Macios i Anna Oksiuta. Kraków: Wydawnictwo Uniwersytetu Jagiellońskiego. 
Eco, Umberto. 1996. Semiologia życia codziennego. Tłum. Joanna Ugniewska i Piotr Salwa. Warszawa: Czytelnik.

Fiske, John. 2010. Zrozumieć kulturę popularna. Tłum. Katarzyna Sawicka. Kraków: Wydawnictwo Uniwersytetu Jagiellońskiego.

Fromm, Erich. 2016. Anatomia ludzkiej destrukcyjności. Tłum. Jan Karłowski. Poznań: Dom Wydawniczy Rebis.

Garda, Maria B. 2016. Interaktywne fantasy. Gatunek w grach cyfrowych. Łódź: Wydawnictwo Uniwersytetu Łódzkiego.

Grabarczyk, Paweł. 2019. „Opozycja hardcore/casual”. [w:] Wprowadzenie do groznawstwa, red. Katarzyna Prajzner. Łódź: Wydawnictwo Uniwersytetu Łódzkiego.

Harrison, Robert L., Jenna Drenten i Nicholas Pendarvis. 2016. „Gamer Girls: Navigating a Subculture of Gender Inequality”. Research in Consumer Behavior 18: 47-64.

Jenkins, Henry. 2006. Kultura konwergencji. Zderzenie starych i nowych mediów. Tłum. Małgorzata Bernatowicz i Mirosław Filiciak. Warszawa: Wydawnictwo Akademickie i Profesjonalne.

Juul, Jesper. 2010. A Casual Revolution. Reinventing Video Games and Their Players. Cambridge: The MIT Press.

Kennedy, Helen W. 2002. „Lara Croft: Feminist Icon or Cyberbimbo? On the Limits of Textual Analysis". Game Studies: International fournal of Computer Games Research 2(2). Dostęp: 17.03.2020. http://www.game studies.org/0202/kennedy/.

Kobus, Aldona. 2017. „Podtekst zamiast reprezentacji. Queerbaiting jako strategia sprzedaży”. [w:] Seriale w kontekście kulturowym. Dyskurs, konwencja, prezentacja. Tom 1, red. Daria Bruszewska-Przytuła, Monika Cichmińska, Anna Krawczyk-Łaskarzewska i Alina Naruszewicz-Duchlińska, 144-160. Olsztyn: Instytut Polonistyki i Logopedii UWM.

Lien, Tracey. 2013. "No Girls Allowed. Unraveling the story behind the stereotype of video games being for boys". Dostęp: 17.12.2019. https:// www.polygon.com/features/2013/12/2/5143856/no-girls-allowed.

Mäyrä, Frans. 2008. An Introduction To Game Studies. Games in Culture. London: SAGE Publications.

Mortensen, Torill Elvira. 2016. „Anger, Fear, and Games: The Long Event of \#GamerGate”. Games and Culture 1(20): 787-806.

Nooney, Laine. 2013. „A Pedestal, A Table, A Love Letter: Archaeologies of Gender in Videogame History". The International fournal of Computer Game Research 13(2). Dostęp: 17.03.2020. http://gamestudies.org/ 1302/articles/nooney. 
Olchanowski, Tomasz i Jacek Sieradzan. 2011. „Wprowadzenie do problematyki narcyzmu. Od klasycznej koncepcji narcyzmu do narcyzmu kultury zachodniej”. [w:] Narcyzm: jednostka - społeczeństwo - kultura, red. Jacek Sieradzan, 7-70. Białystok: Wydawnictwo Uniwersytetu w Białymstoku.

Pavlounis, Dimitrios. 2016. „Straightening Up the Archive: Queer Historiography, Queer Play, and the Archival Politics of Gone Home”. Television \& New Media 1(16): 579-594.

Ptaszek, Grzegorz. 2019. „Kapitalizm jako źródło kulturowego narcyzmu w epoce późnej nowoczesności”. [w:] Christopher Lasch, Kultura narcyzmu. Amerykańskie życie w czasach malejących oczekiwań, Tłum. Grzegorz Ptaszek i Aleksander Skrzypek, 9-17. Warszawa: Wydawnictwo Akademickie SEDNO.

Scholz, Trebor, red. 2013. Digital Labor. The Internet as Playground and Factory. Routledge, New York: Routledge.

Shaw, Adrienne. 2011. „Do you identify as a gamer? Gender, race, sexuality, and gamer identity". New Media \& Society 14(1): 28-44.

Sikora, Agata. 2019. Wolność, równość, przemoc. Czego nie chcemy sobie powiedzieć, Kraków: Karakter.

Siuda, Piotr. 2012. Kultury prosumpcji. O niemożności powstania globalnych i ponadpaństwowych społeczności fanów. Warszawa: ASPRA-JR.

Spawntaneous. 2019. OMG A GIRL Series. Dostęp: 15.03.2020. https://www. youtube.com/playlist?list=PLEDsO12Ccv9ES1Qlnwu_Gi72udJyhVX yZ.

Taylor, Charles. 2002. Etyka autentyczności. Tłum. Andrzej Pawelec. Kraków: Wydawnictwo Znak.

Terranova, Tiziana. 2000. „Free Labor: Producing Culture for the Digital Economy”. Social Text 18(2): 33-58.

Tomczok, Paweł. 2018. „Narcyzm i historia. Narcyzm zbiorowy i narcyzm indywidualny $\mathrm{w}$ historiach alternatywnych i powieściach historycznych ostatnich lat”. Zagadnienia Rodzajów Literackich 61(3): 89-104. Tuła, Magdalena. 2013. „Dlaczego mężczyźni grają w FIFA, a kobiety w The Sims? Przemoc symboliczna w grach komputerowych". Homo Ludens 1(5): 279-288.

Wojtyna, Miłosz. 2018. „Narcyzm, obraz, disco polo”. Zagadnienia Rodzajów Literackich 61(3): 21-37. 


\title{
Abstract, keywords, about the author
}

\begin{abstract}
Manifestations of narcissistic consumption in selected gamer environments

The aim of this article is to show how the narcissistic identity of gamers and modes of consumption corresponding with it affect the forms of participation in video games culture. I have analyzed the changing ways in which consumers participate in contemporary popular culture and identified the common image of the gamer which has emerged at the end of the last century. By recalling the key events concerning gamer communities from the last few years, such as the rise of Gamergate movement, I wanted to show the impact of mechanics of exclusion still existing in conservative communities of video game fans.
\end{abstract}

Keywords: video games culture, digital games, gamer, narcissism, identity

Magdalena Kozyra, PhD student in Cultural Studies at the Faculty of Polish Studies at the Jagiellonian University. Her research interests are related to contemporary popular culture, her doctoral project is focused on the experience of failure in video games.

E-MAIL: m.e.kozyra@gmail.com 